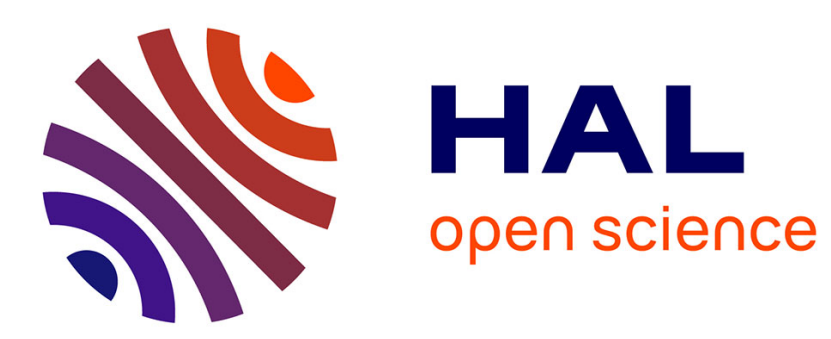

\title{
The Name of the Vestal, or When a Vestal is Named
}

Claudia Beltrão, Patricia Horvat

\section{To cite this version:}

Claudia Beltrão, Patricia Horvat. The Name of the Vestal, or When a Vestal is Named. Archimède: archéologie et histoire ancienne, 2018, Archimède $n^{\circ} 5$. Archéologie et histoire ancienne, 5, pp.175-184. halshs-01826414

\section{HAL Id: halshs-01826414 https://shs.hal.science/halshs-01826414}

Submitted on 29 Jun 2018

HAL is a multi-disciplinary open access archive for the deposit and dissemination of scientific research documents, whether they are published or not. The documents may come from teaching and research institutions in France or abroad, or from public or private research centers.
L'archive ouverte pluridisciplinaire HAL, est destinée au dépôt et à la diffusion de documents scientifiques de niveau recherche, publiés ou non, émanant des établissements d'enseignement et de recherche français ou étrangers, des laboratoires publics ou privés. 


\section{ARCHIMĖDE N'5

1 DOSSIER THÉMATIQUE : HUMOEROTICA

\section{ACTUALITÉ DE LA RECHERCHE : DES FEMMES PUBLIQUES. GENRE, VISIBILITÉ ET SOCIABILITÉ DANS L'ANTIQUITÉ GRECQUE ET ROMAINE}

108 Marie AUGIER

Des femmes en capacité d'agir. Introduction au dossier

113 Louise BRUIT ZAIDMAN

«L'enfant du foyer ». Des statues pour les filles et les garçons initiés à Éleusis au nom de la cité

124 Hélène CASTELLI

Pèlerines à Épidaure. Femmes, guérison et publicité dans un sanctuaire panhellénique au IVe siècle av. J.-C.

134 Marie-Laure SRONEK

Des femmes invisibles dans l'Athènes classique ? Les effets du travail pour une redéfinition de la place des femmes dans la vie publique

145 Annalisa PARADISO

Femmes lydiennes et crises dynastiques

\section{Sandra PÉRÉ-NOGUÈS}

Sur les traces de Philistis, « reine » de Syracuse : quelques réflexions sur la visibilité des femmes dans les sources monétaires

165 Christine HUE-ARCÉ

Grec(que)s contre Égyptien(ne)s dans les enteuxeis ptolémaïques : la question du genre dans les $P$. Enteux. 79 et $P$. Enteux. 82

\section{Claudia BELTRÃO and Patricia HORVAT}

The Name of the Vestal, or When a Vestal is Named

185 VARIA

246 LA CHRONIQUE D'ARCHIMÈDE

\section{@creative @) (1) ()}




\section{THE NAME OF THE VESTAL, OR WHEN A VESTAL IS NAMED}

\author{
Claudia BELTRÃO \\ Professor in Ancient History \\ Universidade Federal do Estado do Rio de Janeiro \\ Nero-UNIRIO, Nereida-UFF, Brasil \\ crbeltrao@gmail.com
}

\author{
Patricia HORVAT \\ Researcher in Ancient History, \\ Arts and Psychoanalysis \\ Universidade Federal do Estado do Rio de Janeiro \\ Nero-UNIRIO, Nereida-UFF, Brasil \\ patriciahorvat@gmail.com
}

ABSTRACT

The Vestals were not to be named and usually they were not, so we know few names of priestesses when compared to the best-known names of Roman male public priests. Rare examples of priestesses' names appear in contexts that allow us to question the categories presiding their identification. Livy's Republican Vestals are named especially when they are criminally indicted de incestum, a particularly serious religious offence in Rome and punishable by death. Without developing the debate on the nature of the penalty, we will examine the exceptionality of the Vestal named in the framework

\section{MOTS-CLÉS}

Vestals,

Roman religion,

incestum,

Livy,

gender,

personal name. of Roman public religion in Livy, asking for what these mentions can tell us about gender in Republican Rome.
La Vestale ne devait pas être nommée et ne l'était généralement pas, en comparaison avec les noms plus bien connus d'autres principaux prêtres à Rome. Les rares exemples de Vestales nommées apparaissent dans des contextes permettant d'interroger les catégories qui président à leur nomination. Les Vestales républicaines dans les récits de TiteLive sont nommées notamment quand elles sont accusées du crime d'incestum, une faute particulièrement grave à Rome et punissable de mort. Sans discuter la nature de la peine, nous examinerons I'anomalie que représente, dans la religion publique romaine telle qu'elle est présentée par Tite-Live, la Vestale désignée par son nom personnel, et nous nous demanderons ce que signifie cette nomination dans le cadre des rapports de genre.

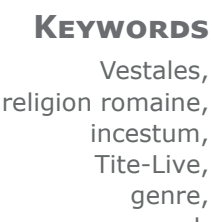

nom personnel. 
In a dramatic passage of the speech de domo sua, Cicero contrasts the madness and religious pollution attributed to Clodius with the highest example of purity, the Vestal, and presents himself as the champion of the castissima Virgin of Vesta [1]. Certainly, the stark contrast reveals Cicero's political intentions, but also shared ideas and beliefs held by Roman society, as an orator should consider the audience's expectations to be successful. For Cicero, Clodius was a menace to the Roman order, and responses to such threats usually occurred within religious discourse and practice.

Roman social order seems to have been marked by complex means, and the study of religious beliefs and practices may be a sound starting point for its analysis. Religion not only relates to individual feelings or perceptions, but to social groups, and this is one of the main factors that establish and maintain cohesion and social order, whose contents are always culturally defined. Furthermore, religion is one of the most important mechanisms which construct the gender logic of a society [2]. Gender Studies have brought important insights to the research of the ways by which the social roles of individuals are elaborated and how their representations are developed and consolidated, establishing identities that act on human beings, taken individually and collectively [3].

Modern knowledge about Vestal Virgins depends on a lacunar and sparse documentation. As far as the manuscript tradition is concerned, except for Cicero all sources of information identifying Vestals by name

[1] Cicero, de domo sua, 144.

[2] KING 2004.

[3] Butler 1990; ThÉBAud 1998; Boehringer \& CUCHET 2011.

[4] For a comprehensive study of Vesta's priesthood in the Roman Empire that deals with a wide variety of sources, see MEKACHER 2006.

[5] On this methodological problem, see RüPKE 2008.

[6] The aedes Vestae was not a templum, but the house of the goddess, the sacred flame, and her penus where are from Augustan and later periods. Likewise, epigraphic sources with names of Vestals are late [4]. This means that the few records of Vestals' names prior to the first century BCE depend on authors who wrote sometimes centuries after the alleged occurrences they narrate. These authors had had their own intentions and interests, and we must be careful in dealing with their information, notably by disregard changes of the priesthood and of Roman public religion itself. However, this methodological problem is also valid for almost all Republican priesthoods and religious institutions before the second century BCE and, based on the available data, it was composed a satisfactory picture on the nature and characteristics of this priesthood which we should consider [5].

The public priesthood of Vesta was composed of six priestesses who entered the office as children. They lived in the atrium Vestae, in the forum Romanum, adjacent to the aedes Vestae [6], where they performed their main ritual activities pro populo. They were preceded by lictors when moving into the city, and the consuls and magistrates should move away and lower the fasces in their presence [7]. Vestals could use carriages in the urbs when and where this was forbidden to anyone else [8]; as witnesses in court they were exempt from the obligation of oath [9], and when they died they were buried inside the pomerium [10]. The priestesses had, therefore, exceptional prerogatives and powers.

Above all, Vestals were expected to have a prominent level of moral perfection and physical purity, as well the Palladium and other sacred objects were kept safe, as it was never inaugurated by augurs: Gellius, Noctes Atticae, 14, 7, 7. On the aedes Vestae see Horvat 2007. [7] Seneca, Controversiae, 6, 8, Suetonius, Tiberius, 2.

[8] Tacitus, Annales, 12, 42.

[9] Gellius, Noctes Atticae, 7, 7, 2 and 10, 15, 31. If someone sentenced to the capital punishment found a Vestal in his way to execution, he was released: Plutarch, Numa, 10.

[10] Servius, Annales, 11, 206. 
as to abstain from bodily contact with other human beings. The children chosen by the pontifex maximus to the priesthood could not bear any physical defects, including slight speech or hearing deficiencies, as well as to enter the office in their captio, they need to have living parents (patruma et matruma) legally married, showing that they were free from death stain. Moreover, their parents could not occupy or had occupied themselves with professions reputed as sordid [11]. The captio removed the new Vestal from the potestas of her paterfamilias and guaranteed her the right to a will [12], which indicates that the priestess, legally speaking, was not a member of a Roman family, since her own property would not necessarily return to her family when she died. If a Vestal died intestate, her property reverted to the public treasury, the aerarium. But if our sources reveal Vestals' connections with members of their families, their separation from their own families was complete in law, and they were not tied to any private worship [13]. In the same way, the Vestals had special seats in the ludi scaenici and a prominent place in the public life, in the very centre of Roman power. So, whereas Roman women only existed by law connected to a man, the Vestal seems to have been exempt of guardianship, or, in some sense, she was under the tutela of the city itself. In short, in terms of public law and the religio domestica, the Vestals were excluded from ordinary private and family relations to fulfil their religious functions for the whole Roman community [14], and the res publica gave them privileges, based on the sacred law [15].

Their most famous religious duty was the maintenance of the sacred fire in the aedes Vestae, whose existence points to the prosperity and safety of the urbs [16]. It is possible that the Vestals were a priesthood originally related to rites of purification that gradually received increasing political prominence, connecting public and family worships. The link between the public priesthood and the domestic religion is expressed by the necessity of the mola salsa for public and private immolationes [17], and other suffitamenta for the rituals, and the relationship between the public hearth in the forum Romanum and the domestic fireplaces indicate that the Vestals were directly or indirectly present in every Roman ritual [18]. In addition, they were responsible for the safeguarding of some of the pignora imperii [19], as the Palladium, supposedly brought from Troy to the Latium by Aeneas, protecting the urbs and its imperium [20]. Therefore, the Vestals were at the centre of Rome's religious activity, while they also turn private worship possible. Even in spatial terms, the Vestals were at the heart of Roman public activity, the forum Romanum, and it was considered nefarious if they or their sacred objects left Rome [21]. This connection between the priesthood and the city space also indicates the huge importance of the priesthood. They have, then, a special religious and legal status in the (male) Roman state, even acting as a kind of public notaries, for example, by keeping famous wills [22], contracts, and other documents. We can say that they were fully dedicated pro populo. However, when Rome was threatened, the priestesses, custodes of some of the pignora imperii and the public hearth, were under suspicion.

The Vestal Virgins have been extensively studied from many viewpoints, especially on the nature of the priesthood, the prosecutions by charges of loss of virginity and the fate of the convicted priestesses.
[11] Gellius, Noctes Atticae, 11, 2, 1-5. On the proceedings of the captio, see MeKACHER \& VAN HAEPEREN, 2003.

[12] Gellius, Noctes Atticae, 12, 73.

[13] Gellius, Noctes Atticae, 7, 9. See GuIzzi 1968 for an extensive study on the priesthood legal questions. Vestals' relationship to their own family is quite problematic. In inscriptions dedicated to the Vestal Flavia Publicia, e.g., two names her as filia. This designation may be an exception, but it may also express some tension between the priestly ideal and the daily practices. Note that literary sources also indicate Vestals linked to relatives, usually parents or siblings.

[14] MustakalLio 1992: esp. 62.

[15] Kroppenbeg 2010; Guizzi 1968.

[16] Ovid, Fasti, 6, 291-292 ; 439-440; Dionysius, 2, 66, 2; Plutarch, Numa, 9; Festus, s.v. ignis Vestae.

[17] Plautus, Amphitruo, 2,109; Cicero, De divinatione, 2, 16, 3; Dionysius, 24, 2; Festus, 124L.

[18] This link was emphasised by Augustus when he became pontifex maximus, by uniting Vesta's public hearth to his domus in the Palatine, instead of using the domus publica, that is, the official residence of the pontifices maximi up to Julius Caesar. See e.g. STAPLES 1998: 15, for whom the Vestals, being not part of any private worship, belong to all Roman families.

[19] On the pignora imperii see, e.g., FERRI 2010: 199-205.

[20] Livy, 26, 27, 4 ; 5, 52, 7; Cicero, Philippicae, 11, 10, 24 ; Ovid, Tristia, 3, 1, 29. Vestal as the only person able to see and touch the Palladium: Plutarch, Numa, 9, 8 ; Ovid, Fasti, 6, 4, 7, possibly apart from pontifex maximus: Dionysius, 2, 66. The pignora imperii were sacratissimi and Roman literature is plenty of dramatic narratives about invasions or fires in which it was necessary to move such objects, e.g. Livy, 5, 40-42 ; 26, 27, 4; Plutarch, Camillus, 21-22.

[21] Cf. esp. Livy, 5, 52 on the Roman sack by the Gauls. [22] e.g. the wills of Julius Caesar: Suetonius, Iulius, 83, 1, of Antonius : Plutarch, Antonius, 58, and Augustus : Suetonius, Augustus, 101, 1; Tacitus, Annales, 1, 8. 
The fate of the declared unchaste Vestal [23] has led to different conclusions, and we do not intend to contradict existing approaches and interpretations, but rather to think based on them the ways in which these Republican priestesses were named in the historical record derived from the manuscript tradition. As a rule, the Vestals were not identified by name, so we know few names from our sources. Rare examples of priestesses' names appear in passages that lead us to ask for the categories presiding their identification. In our sources, Vestals are named especially when they are criminally indicted de incestum [24], a particularly serious religious offence in Rome and punishable by death [25]. Given the limited scope of this paper, we will concentrate on Livy's accounts, which gives us the greatest number of names of Vestals in circumstances connected with major institutional changes [26]. Following the assumptions of Eurykleia's research team [27], and without developing the debate on the nature of the penalty, we will consider that the reports of condemned Vestals should not be interpreted as isolated cases, but rather as a phenomenon based on specific discourses in which Roman society expressed its social, political and religious order. We will first present a brief overview of the current debate on Vestals' crimen incestum. Then, we will retrieve Livy's references to indictments of priestesses to offer some remarks on the personal name of the Vestal which deals with Roman gender logic.

\section{THE CRIMEN INCESTUM AND THE DEATH OF THE UNCHASTE PRIESTESS: THE GENERAL LINES OF THE DEBATE}

Roman public priesthoods had great visibility and political relevance, and the male priests occupy political and military offices. The Vestals, by their gender, could not occupy offices like these, and Jörg Rüpke, based on his prosopographical research [28], drew attention to the fact that while male priests enter the historical record by obtaining the priesthood, in the case of the Vestals it is much more frequent that their names are known for their removal from the priestly office. Mentions of the crimen incestum are the primary means by which their names are known in the historical tradition, and until the fourth century CE there are records of indicted Vestals [29].

Convictions and ritual deaths of Vestals have received much attention from modern historians, especially in researches linked to the theme of ritual impurity and, to some extent, based on the authoritative Mary Douglas' work on the concept of impurity. Following the ideas of Émile Durkheim, Douglas argued that if impurity means disorder, cases of impurity reveal what a society values as order, and, as a consequence of physical or moral impurity, the individual becomes unfit to perform rituals and take care of the communication with the gods [30]. In one of the most outstanding approaches on the priesthood, Mary Beard, based on Douglas' interpretation of human body, as well as her theory on "interstitial beings" as sources of pollution and fear, brought an important contribution to the understanding of the status of the Vestals, whose prominent religious powers, Beard argues, derived from their interstitial status between matrons and virgins [31].

In the same way, Georg Wissowa's influential thesis that the unchaste Vestal was a prodigium was challenged by Tim Cornell [32], for whom the loss of virginity was announced by prodigies, but was not a prodigy per se. In fact, many studies in the last years have problematized former interpretations of the ritual that followed the conviction of a Vestal by incestum.
[23] Castitas means the state of purity and it is usually linked to the expected behaviour of the Vestals. See esp. Cicero, de legibus, 2, 29.

[24] Incestum, a type of qualified stuprum by the fact that the involved parties could not get legal marriage. The term derives from in castum, the very antithesis of chastity, cf. Thesaurus Linguae Latinae, 7, 1, 893-896. Note that Cicero uses the term nefas in dealing with the Vestal crime and the verdict of the pontiffs in Att., 1, 13, inserting it in the context of religious crime.

[25] Livy, 8, 15, 7. The two most extensive descriptions of the ritual that followed Vestal's condemnation for incestum are Dionysius, 2, 67, 3-4 ; 8, 89, 5 and Plutarch, Numa, 10, 4-7, Quaestiones Romanae, 96. The convicted Vestal was taken in a litter to the sceleratus campus at Porta Collina, where she was enclosed in an underground chamber, either near the wall or even under the wall, and a prayer was made by the pontifex maximus. Priests witnessed the Vestal entrance into the chamber, which was sealed and covered. Plutarch adds that bread, water and a lamp were placed in the chamber, and Dionysius says that the convicted Vestal received no funerary monument.

[26] Named female characters in the narrative of Livy are being mapped by UNIRIO'S research team for the Eurykleia database.

[27] On the international research project Eurykleia see: http://eurykleia.hypotheses.org/

[28] RÜPKE 2008 for the lists of Vestals' names.

[29] RÜPKE 2008: 36-38.

[30] Douglas 1966: esp. 24-27, 80-82.

[31] BEARD 1980. She also made a critical re-reading of the theme later: BEARD 1995.

[32] CORNELL 1981. 
The crimen incestum was a special category of religious offences, which could not be expiated [33], and Cornell draws attention to the extraordinary character of punishment in terms of criminal and sacred law. Offences against the gods were subject to court proceedings, under magistrates' jurisdiction, and a citizen guilty of impiety could be admonished or even socially degraded. Vestals' crimen incestum, however, as they were not worldly women, was judged by the college of the pontiffs, and the pontifex maximus, which had some disciplinary powers over other priests of this college [34], seems to have had an extraordinary power over the priestesses. Cornell also pointed out that if other priesthoods included the possibility of compulsory or voluntary abdication, Vesta's priesthood appears to have been unique for allow abdication only after thirty years of service. Likewise, if other priests who committed errors or offences could expiate them by the repetition of the ritual action or by a piaculum, a fine, or even the resignation of the priesthood, the incestum of a Vestal was inexpiable. This offence was regarded as necessarily deliberate, dolo malus, and there was no possible atonement, according to the distinction of Q. Mucius Scaevola [35].

Since then, many researches have been dedicated to the crimen incestum and to the exceptionality of the Vestals [36], broadening the debate. Ariadne Staples, for example, analysed the literary evidence examining who were the involved parties, and how those charges were investigated [37]. Holt Parker, in turn, analysed the relations between the Vestal body and the walls of Rome and, highlighting the similarities between the prodigies and the unchaste Vestal, has argued that the prodigies pointed to the problem of pollution [38]. In these terms, it is not surprising that the erotic seduction of a Vestal and the loss of virginity were considered the most serious religious offence and threat to the Roman social and religious order. Parker, following some postulates of René Girard, has also argued that the convicted Vestal was the scapegoat of a sacrifice that aimed at the restoration of the social order, calling attention to the place of the burial, next to or in the city's wall, to support his thesis that the unchaste Vestal had to be kept on the borders of the pomerium [39]. However, if the Vestal buried alive was a sacrifice is a matter of interpretation, since no source sustains this thesis [40], and Girard's ideas are of little or no use for an analysis of Roman ritual logic. In fact, the convicted Vestal, a source of religious pollution, would not be a suitable victim to be offered to any Roman god [41].

Some years ago, an influential study by Robin L. Wildfang, who exhaustively collected sources on the Vestals from the end of the Second Punic War to the first century $B C E$, re-evaluated the religious tasks of the priesthood, concluding that virginity and the general state of purity were the conditio sine qua non to the performance of their religious duties, which were bounded to rites of cleansing and purification of the city. She pointed out that, for the priestesses, the obligation of sexual abstinence was permanent, and not circumstantial as the physical purity required of male religious officials at the ceremonies they performed [42]. Therefore, the Vestal lived in a perennial ritual state throughout, at least, the thirty years of priesthood. Likewise, living in this permanent state that required a perennial sexual abstinence, unlike other Roman men or women, they were free from the patria potestas, as well as from the typical ties of subordination to a male guardian that characterised the legal status of women in Roman Republic (tutela mulierum). The loss of virginity was then the most serious of religious crime committed by a Vestal, and the existence of an unchaste priestess meant a continual offence to the gods, the gravest religious crime that could only be purged by the total removal of the offender from the realm of living beings [43].

These studies are some examples of researches that had gradually renewed and expanded modern knowledge on the Vestal Virgins and the crimen incestum, and two recent publications that have brought important contributions to the subject deserve mention. Jack Lennon, for example, renewed the debate on religious purity in Roman antiquity in a study of the
[33] CoRnelL 1981: 36. To WILDFANG 2006: 58-60 the Vestal body was an offer to Vesta. To PARKER 2004: 587588, it was a human sacrifice. See also TAKACS 2008.

[34] VAN HAEPEREN 2002.

[35] Varro, de lingua latina, 6, 30: Q. Mucius ambigebat eum expiari ut impium non posse.

[36] e.g. SCHEID 1986 ; Mustakallio 1992 ; WILDFANG, 2006 ; STAPLES 1998 ; TAKACS 2008 ; SCHULTZ 2010a; Lennon 2014.
[37] STAPLES 1998.

[38] PARKER 2004.

[39] PARKER 2004: 570, 576-585. Also, CORNELL 1981:

36-7 and MuSTAKALLIO 1992: 56-57.

[40] SCHULTZ 2010b.

[41] Cf. PResCendi 2007: 241.

[42] WILDFANG 2006.

[43] Cf. Lovisi 1998: 705. 
major forms of ritual impurity of late Republican Rome and early principate, based on literary sources [44]. He has reinforced the idea that the unchaste Vestal was an anomaly, a pollution or a source of pollution to be removed from the city, and her removal had to be done in such a way that the city did not incur in new religious impurities. The Vestal was removed from the human community, and her burial alive promoted the restoration of the order that her crimen had violated. The very name of the place of burial, campus sceleratus [45], clearly reveals the religious implications linked to incestum, a marginal place in the frontier between inside and outside of the urbs. Removed from the face of the earth in an unidentified underground chamber, she was not summarily executed, for this would also be an offence to the gods, especially to Vesta, but her physical existence was erased from the city.

Finally, J. H. Richardson has renewed the question of the ritual death of the convicted Vestal, asking whether the source of the antiquarians on these deaths would be the Annales maximi, based on the information that besides prodigies, the trials of Vestals were a topic of the pontifical records [46]. For him, the main question regarding the ritual murder is: was it in fact an execution? If the condemned Vestal had violated a fundamental rule of the priesthood, the ritual can be seen as a punishment, but Richardson's criticism to the execution's hypothesis is very coherent [47]. If we can trust Dionysius and Plutarch, and water and food were deposited in the underground chamber in which the Vestal considered guilty was closed, he asked, what is the meaning of provisions for whom should die? Perhaps to avoid, as Plutarch suggests, the responsibility for Vestal's death, but the ritual seems too elaborate to be a mere execution of capital punishment. Richardson also draws attention to the fact that two lived burials of Vestals were recorded at a time immediately prior to the Second Punic War, and on other two occasions (216 and 113 BCE) a burial occurred in times of danger to Rome. Such deaths were accompanied by other rituals, notably the lived burials of the Greek and Gallic couples in the forum Boarium [48].

In fact, such indictments were rare in Roman historical records. There are just 21 cases of crimen incestum throughout the existence of the priesthood in Rome. Thus, the Romans seem to have used the Vestals as symptoms of huge problems affecting the city. These accusations occurred at times of military disasters and striking social conflicts, pestilences or diseases, and they were anticipated by prodigies. On this basis, we will observe selected passages from
Livy in which the nominations occur in contexts of indictments that can shed light on the relationship between Rome and the body and name of the Vestal. We are interested, first and foremost, in the mentions themselves, not in the question of their historicity.

\section{NAMING VESTALS IN LIVY'S NARRATIVES}

Livy's first mention of a Vestal occurs in the very first lines of his $A b$ urbe condita, naming Rhea Silvia, mother of Remus and Romulus, in the mythical Alba Longa [49]. She is, strictly speaking, the first Vestal named and at the same time the first one sentenced to confinement in Livy's work. Therefore, Livy connects the founding myth of Rome with a Vestal and a god, Mars, the twins' father. The second name is Oppia, convicted by incestum, in a brief mention of a case dating back to $483 \mathrm{BCE}$, inserted in the report of menacing portents during external wars against Veii and the Volscians. For Livy, Oppia's death was a clear penalty (poena) for her unchastity:

To increase the general anxiety which was now felt, portents implying the anger of the gods were of almost daily occurrence in the City and the country. For this expression of divine wrath, no other reason was alleged by the soothsayers, when they had enquired into it both officially and privately, sometimes by inspecting entrails and sometimes by observing the flight of birds, than the failure duly to observe the rites of religion. These alarms at length resulted in the condemnation of Oppia, a Vestal virgin, for unchastity, and her punishment [50].

[44] LENNON 2014.

[45] Cf. CoARelli 1993; Festus, 448-449 L : Sceleratus campus app<ellatur prope portam Col>linam in quo virgin <es Vestales, quae incestum> fecerunt, defossae sunt $v>$ ivae...

[46] Richardson 2011. Cf. Cicero, De haruspicum response, 13 ; Livy, 4, 44, 11-12 ; 8, 15, 7-8; Dionysius, $2,67,3$; 8, 89, 4-5 , 9, 40, 3. See also LOVISI 1998.

[47] GRADEL 2002: 297 define it as an execution.

[48] As ECKSTEIN 1982 has demonstrated, these cases were clearly linked to military and political crisis. [49] Livy, 1, 3-4. Eurykleia's database follows, whenever possible, the editions of Perseus Digital Library.

[50] Livy, 2, 42, 10-11 : Accessere ad aegras iam omnium mentes prodigia caelestia, prope cotidianas in urbe agrisque ostentantia minas; motique ita numinis causam nullam aliam vates canebant publice privatimque nunc extis, nunc per aues consulti, quam haud rite sacra fieri; qui terrores tamen eo evasere ut Oppia virgo Vestalis damnata incesti poenas dederit. English translation by B. O. Foster by B. O. Foster, Loeb, 1919. 
In Livy's report there is no trace of what Oppia would had done, but simply the statement of the maleficent signs because of the Vestal's unchastity. The Vestals should be public models of excellence and virtue, hence Postumia, the third Vestal named by Livy, was admonished in C. $420 \mathrm{BCE}$, by the pontifex maximus for her clothes and attitudes that aroused suspicions about her chastity:

The same year a Vestal virgin named Postumia was put on trial for unchastity. She was innocent of the charge, though open to suspicion because of her pretty clothes and the unmaidenly freedom of her wit. After she had been remanded and then acquitted, the pontifex maximus, in the name of the college, commanded her to abstain from jests, and to dress rather regarding sanctity than coquetry [51].

This is a brief mention in an account of the disturbing events after a Roman defeat to Veii, on the election of quaestors and an agrarian law, on the topos of the struggle between patricians and plebeians. Postumia probably was the sister of M. Postumius, a military tribune blamed for the defeat of Rome to Veii in the preceding year [52]. Nevertheless, a caveat is necessary here. We are dealing with a narrative that is, in the main, talking about Roman élite's views, based on Livy's contemporaries shared ideas and beliefs, and his incidental Vestals' characters have a heavily symbolic role related to male power [53]. While reading these somewhat "anti-heroines", a methodological problem is to what extent we can rely on them in search of information to the study of gentes or families of past centuries, or of the supposed real women themselves. We are thus dealing with a kind of intractable material in terms of historicity, given the absence of Republican sources on these characters [54].

Vestals accused of incestum based on their more elegant and sophisticated appearance than was suitable to a public priestess are not unusual in our sources. The Vestal Virgin was a public person, she was constantly in the public eye and her behaviour was subject to a high level of social expectation. Postumia was acquitted, but the same did not occur to Minucia, c. 337 BCE, which was convicted, and her only explicit lapse in behaviour is her graceful outfit. In an apparently neutral speech, the brief mention of Minucia appears as an excursus in the report of the Samnite Wars and the first plebeian praetor election, as an example of bad religious behaviour:

In that year the Vestal Minucia, suspected in the first instance because of her dress, which was more ornate than became her station, was subsequently accused before the pontiffs on the testimony of a slave, and having been by their decree commanded to keep aloof from the sacred rites and to retain her slaves in her own power, was convicted and buried alive near the Colline Gate, to the right of the paved road in the Polluted Field - so called, I believe, on account of her unchastity [55].

After Minucia, a brief title in Periochae 14 identifies another Vestal, Sextilia, condemned by incestum and buried alive, c. 273 BCE. The Periochae are simple summaries with no literary elaboration, but other titles of the section indicate a severe crisis, notably due to military conflicts involving Pyrrhus and Carthage. There are also reported prodigies, specifically a lightning that had overthrown the very statue of Jupiter in the Capitol, a particularly dangerous sign. Another title, in Periochae 20, states only that The Vestal Tuccia is convicted of incestum, among several titles dating back to C. 230 BCE on Italic and foreign wars [56].

The next Vestals identified by name are Opimia and Floronia, c. $216 \mathrm{BCE}$, in the context of the Roman defeat at Cannae:

They were terrified not only by the great disasters they had suffered, but also by many prodigies, and in particular because two Vestals, Opimia and Floronia, had in that year been convicted of unchastity. Of these one had been buried alive, as the custom is, near the Colline Gate, and the other had killed
[51] Livy, 4, 44, 11-12 : Eodem anno Postumia virgo vestalis de incestu causam dixit, crimine innoxia, ab suspicione propter cultum amoeniorem ingeniumque liberius quam virginem decet parum abhorrens. Eam ampliatam, deinde absolutam pro collegii sententia pontifex maximus abstinere iocis colique sancte potius quam scite iussit. English translation by B. O. Foster, Loeb, 1922.

[52] Livy, 4, $31 ; 41$.

[53] See MARTINI 2004.

[54] On this methodological problem, see the Introduction of RÜPKE 2008.
[55] Livy, 8, 7-8 : Eo anno Minucia Vestalis, suspecta primo propter mundiorem iusto cultum, insimulata deinde apud pontifices ab indice servo, cum decreto eorum iussa esset sacris abstinere familiamque in potestate habere, facto iudicio viva sub terram ad portam Collinam dextra viam stratam defossa Scelerato campo; credo ab incesto id ei loco nomen factum. English translation by B. O. Foster, Loeb, 1926.

[56] Tuccia's case is mentioned by other authors, for whom she was acquitted de incestum: Dionysius, 2, 69, 1-3 ; Valerius Maximus, 8, 1 ; Pliny, Naturalis Historia, $28,12$. 
herself. Lucius Cantilius, a secretary to the pontiffs -one of those who are now called the lesser pontiffs - had been guilty with Floronia, and the Pontifex Maximus had him scourged in the Comitium so severely that he died under the blows. Since in the midst of so many misfortunes this pollution was, as happens at such times, converted into a portent, the decemvirs were commanded to consult the Books, and Quintus Fabius Pictor was dispatched to Delphi, to enquire of the oracle with what prayers and supplications they might propitiate the gods, and what would be the end of all their calamities. In the meantime, by the direction of the Books of Fate, some unusual sacrifices were offered; amongst others a Gaulish man and woman and a Greek man and woman were buried alive in the Cattle Market, in a place walled in with stone, which even before this time had been defiled with human victims, a sacrifice wholly alien to the Roman spirit [57].

The devastating effect of Cannae's defeat to Hannibal is presented here as a result of the alleged actions of Opimia and Floronia, and this is the only reference in the cases reported by Livy to a male accomplice, which was also convicted and whipped to death [58]. However, the absence of mention of the existence or punishment of male lovers in such cases does not necessarily imply their inexistence [59], not even their acquittal, as ancient authors seem to have been focused on the crime and the priestesses themselves. Added to a short title on the sentencing of the Vestals Aemilia, Licinia and Marcia, c.114 BCE, in Periochae 63 [60], without details, these are the mentions to names of indicted Vestals in Livy's work up to the end of the second century BCE.

Cases of incestum no doubts coincide with times of crisis for the urbs, and it is possible to interpret the ritual death of the Vestal as a purification rite for the reestablishment of the pax deorum. The body of the Vestal in Livy's narratives worked then as a catalyser for the alleged violation of the order that brought military defeats, social disasters and prodigies of all kinds. However, what about the name? Why does the name appear in these cases, while in other mentions to Vestals their names usually were not reported?

\section{SOME REMARKS ON THE NAME OF THE VESTAL}

In the Roman androcentric order, woman's body is not something that belongs to herself, but to her father, her husband or her legal guardian. Vestals' bodies, however, belong to the whole city, so these female religious officials should be untouched and untouchable. Sacrosanct, they were elevated to a form of public life in which the Virgo symbolises Rome's ideal feminine element. Captured from the family system, the very place of the worldly women, Vestal Virgins were strongly related to male power but, by their gender, they oversaw idealised female activities, as the maintenance of the sacred fire, the provision of mola salsa and other ritual implements. They acted religiously within the city, performing public rites related to the Roman feminine role, as signa of the goddess and allegories of the female functions inside the city [61], but, above all, they were personified symbols of purity, piety and religious duty. They had a public role and were to be seen always in their religious function. Their virginity meant the highest and perennial form of ritual purity, not suitable for male priests.

The consecration of the symbol and the consequent crystallisation of its meaning occur by the reiteration of the referent Vestal uttered by whomever holds the instituted authority and refer to the allegories necessarily shared by human beings in their collective life. The rituals performed pro populo by the priestesses operated the establishment of the female's metaphor that has the term Vestal as a referent and set up it as the linguistic symbol that points to the symbolic Woman. The priestesses cannot be the object of any male desire taken individually, nor can they be polluted
[57] Livy, 22, 57, 2-6 : Territi etiam super tantas clades cum ceteris prodigiis, tum quod duae Vestales eo anno, Opimia atque Floronia, stupri compertae et altera sub terra, uti mos est, ad portam Collinam necata fuerat, altera sibimet ipsa mortem consciuerat; L. Cantilius scriba pontificius, quos nunc minores pontifices appellant, qui cum Floronia stuprum fecerat, a pontifice maximo eo usque uirgis in comitio caesus erat ut inter uerbera exspiraret. hoc nefas cum inter tot, ut fit, clades in prodigium uersum esset, decemuiri libros adire iussi sunt et Q. Fabius Pictor Delphos ad oraculum missus est sciscitatum quibus precibus suppliciisque deos possent placare et quaenam futura finis tantis cladibus foret. Interim ex fatalibus libris sacrificia aliquot extraordinaria facta, inter quae Gallus et Galla, Graecus et Graeca in foro bouario sub terram uiui demissi sunt in locum saxo consaeptum, iam ante hostiis humanis, minime Romano sacro, imbutum. English translation by B. O. Foster, Loeb, 1929.

[58] On the punishment of the male accomplice, see also Festus, 217, $10 \mathrm{~L}$.

[59] See contra PARKER 2004.

[60] Aemilia, Licinia, Marcia, uirgines Vestales, incesti damnatae sunt, idque incestum quem ad modum et commissum et deprehensum et uindicatum sit re fertur.

[61] On woman as an idea of the imaginary male, see LAMOTT 2001. 
by earthly subjections of the Roman worldly women. It can be argued, therefore, that Vestal is a symbol that consolidates the overlap of gender and sexuality that comes to characterise women in Livy's discourse, fixing them in their biological sex [62]. She personifies the idea of a woman who is hindered, the forbidden woman, a universal mother who exercises her protective and provider role, a constant and stable maternal lap that ensures energy, food, stability and continuity of the Roman life, and consequently guarantees the safety and permanence of the urbs.

Naming the priestess as Vestal, a name not individualised, transcendentalises her, making her as inaccessible and powerful as the goddess Vesta, substantiating her sense of protection of Roman order in a successive religious structuring that includes the Roman family, the city and the very Roman state. In a way, the Vestal is a religious symbol, a sacred entity for the sake of the urbs. In other words, she symbolises the power of the goddess Vesta [63].

It is very known that Roman women had no personal names, for they only bore the name of their families - sisters would simply bear the same name, with a number to distinguish between them. We wonder that Roman women should be seen, in some sense, as objects pertained to their families and constructed as male abstractions, imaginary figures working as the "otherness" within the agnatic Roman family as well as in Roman social order. By this otherness, the idea of masculinity was constituted and safeguarded [64].

The repertoire of the phantasmagorical characteristics attributed to men and women constituted the binary gender organisation of Rome's community and guaranteed the persistence of the supremacy of one group over the other one. In Roman gendered social logic, the woman's body was owned by her father, husband or her legal guardian. Their social existence depended on the name of their agnatic family, that is, on their male relatives. But a Vestal's body was not to be owned by any private man, as she, in some sense, personified the very goddess Vesta and embodied the res publica. Her "personal" name, that is, her former family name, from which she was "captured" by the pontifex maximus for the whole city, pro populo, was not to be mentioned.

As the absolute otherness, for she was elevated to a symbol, she is akin only to herself and linked to the city. The Vestal ensured the urbs Romae itself. Her virginity and chastity are indices that make the symbol understandable. Virgin and "well-behaved", in a permanent ritual state, she balanced the male social order. Convicted by incestum, the Vestal was turned by the college of pontiffs from the symbol Virgo to a sexually active woman, whether by her clothes or behaviour stimulating male desire, or by suspicion that she was "owned" by a man. In both cases, the city needs to supress her, for she created a great danger to the city, disrupting the Roman sacred order. She must fade away. There was a religious and moralistic link between the crimen incestum and Roman public disasters, and the male collective acted out its own cohesion by projecting its ideas of ritual purity and the city's integrity on female bodies. Turned to the mundane, then, her name was to be mentioned as a sign of desecration and individualisation. She descended, then, into the mundane reality of what was intended and desired to be the common woman's social place as an earthly being, polluting her capacity to perform her sacred role and religious functions.

The renaming of the indicted priestess operated her return to the numerical position in a Roman family, position destined for the instrumental materiality of the daily life which, however, could no longer be lived by her. The name as a marker of individualisation and, in the Roman onomastic logic, a family referral, removes the Vestal from the necessary universality of a symbol to immerse her in the contingent particularity of a feminine body [65]. To pronounce a Vestal's personal name could work semantically as a sign of corruption which stimulated religious fear and anxiety. This was perceived as a strong disruptive factor to the very existence of the human group, which obliterated the human capacity of reflexion, created emotional instability and encouraged the community to the necessary subjection to the Roman order.

As an ancient historian, Livy was more occupied with the moral dimensions of his narratives than their historicity. We can realise that his work conveys much about the attitudes and beliefs of his contemporaries. Livy's audiences seem to be prepared to read or hear that the way a woman gets dressed was a sign of her chastity, and that the death of the highest priestess was better than her loss of virginity.

[62] On this theme, see D'Or 1985, FreUd 1992 and, especially, SCHROEDER 1998.

[63] See SCHEID 1986, an important study of the religious phenomenon of human personification of gods.

[64] BeLtrão 2007, GLEASON 1995, WinkLER 1990.

[65] On the name, the universal, the individual and the particular, see the influent monograph by ZABEEH 1968. 
BeARD, Mary, 1980, «The Sexual Status of Vestal Virgins », Journal of Roman Studies 70, p. 12-27.

BeARD, Mary, 1995, « Re-reading (Vestal) Virginity », in R. Howley \& B. Levick (ed.), Women in Antiquity: New Assessments, London, p. 21-48.

Beltrão, Claudia, 2007, "Tirocinium fori: o orador e a criação de homens no forum romanum", Phoînix 13, p. 52-66. Boehringer, Sandra \& Sebillotte Cuchet, Violaine, 2011, Hommes et femmes dans l'Antiquité grecque et romaine. Le genre: méthode et documents, Paris.

BuTLeR, Judith, 1990, Gender Trouble: Feminism and Subversion of Identity, New York.

CoARelli, Filippo, 1993, s.v. campus sceleratus, in E. Steinby (ed.), Lexicon Topographicum Vrbis Romae, 1, Roma. Cornell, Tim, 1981, «Some observations on the crimen incestum », in Le délit religieux dans la cité antique, table ronde à Rome, 6-7 avril 1978, Rome (Collection de l'École française de Rome 48), p. 27-37.

DoR, Joël, 1985, Introduction à la lecture de Lacan. L'inconscient structuré comme un langage, Paris.

Douglas, Mary, 1966, Purity and Danger: An Analysis of Concept of Pollution and Taboo, London - New York.

ECKSTEIN, Arthur, 1982, « Human Sacrifice and Fear of Military Disaster in Republican Rome », American Journal of Ancient History 7, p. 69-95.

FERRI, Giorgio, 2010, Tutela urbis. Il significato e la concezione della divinità tutelare citadina nella religione romana, Stuttgart.

GleASON, Maud, 1995, Making Men: Sophists and Self-Presentation in Ancient Rome, Princeton [tr. fr. Sandra Boehringer \& Nadine Picard, Mascarades masculines. Genre, corps et voix dans l'Antiquité grecque et romaine, Paris, 2012].

Freud, Sigmund, 1992, AE I. Publicaciones prepsicoanalíticas y manuscritos inéditos en vida de Freud (1886-99), Buenos Aires.

GrLmore, David, 1991, Manhood in the Making. Cultural Concepts of Masculinity, New Haven - London.

GrADEL, Ittai, 2002, « Jupiter Latiaris and Human Blood. Fact or Fiction? », Classica et Mediaevalia 53, p. 235-254.

GuIZzI, Francesco, 1968, Aspetti giuridici del sacerdozio romano. Il sacerdozio di Vesta, Napoli.

Horvat, Patricia, 2007, « O Templo de Vesta e a Ideia Romana de Centro do Mundo », Phoînix 13, p. $280-291$.

KING, Ursula, 2004, « Religion and Gender: Embedded patterns, interwoven frameworks », in T.A. Medde \& M. E. Wiesner-Hanks (ed.), A Companion to Gender History, London.

KROPPENBEG, Inge, 2010, «Law, Religion and Constitution of the Vestal Virgins », Law and Literature 22,3, p. 418-439. LAMOTT, Franziska, 2001, Die Vermessene Frau. Hysterien um 1900, München.

LeNNON, Jack, 2014, Pollution and Religion in Ancient Rome, New York.

LovisI, Claire, 1998, «Vestale, incestum et jurisdiction pontificale sous la République romaine », Mélanges de l'École française de Rome 110, p. 699-735.

MARTINI, Maria Cristina, 2004, Le vestali. Un sacerdozio funzionale al "cosmo" romano, Bruxelles.

MeKACHER, Nina, 2006, Die vestalischen Jungfrauen in der römischen Kaiserzeit, Wiesbaden.

Mekacher, Nina \& VAN HAeperen, Françoise, 2003, « Le choix des Vestales, miroir d'une société en évolution (IIIe s. a. C.-Ier s. p. C) 》, Revue de l'histoire des religions 200, p. 63-80.

MustakAllio, Katariina, 1992, «The crimen incestum of the Vestal Virgins and the Prodigious Pestilence », in T. Viljamaa, A. Timonen \& C. Krötzl (ed.), The Politics of Cruelty in the Ancient and Medieval World, Krems.

PARKer, Holt, 2004, «Why Were the Vestals Virgins? Or the Chastity of Women and the Safety of the Roman State », American Journal of Philology 125.4, p. 563-601.

Prescendi, Francesca, 2007, Décrire et comprendre le sacrifice. Les réflexions des Romains sur leur propre religion à partir de la littérature antiquaire, Stuttgart.

RIChARDSON, James, 2011, « The Vestal Virgins and the use of the Annales Maximi », in J. H. Richardson \& F. Santangelo (ed.), Priests and State in the Roman World, Stuttgart, p. 91-106.

RüPKE, Jörg, 2008, Fasti sacerdotum. A Prosopography of Pagan, Jewish, and Christian Religious Officials in the City of Rome, Oxford.

Scherd, John, 1986, «Le flamine de Jupiter, les Vestales et le général triomphant. Variations romaines sur le thème de la figuration des dieux », Le temps de la réflexion 7, p. 213-230.

Schroeder, Jeanne Lorraine, 1998, The Vestal and the Fasces. Hegel, Lacan, Property, and the Feminine, Berkeley. Schultz, Celia, 2010a, «The Proper Disposed of a Polluting Presence », in M. Bradley (ed.), Rome, Pollution and Propriety: Dirt, Disease and Hygiene in the Eternal City from Antiquity to Modernity, Cambridge, p. 122-35.

Schultz, Celia, 2010b, « The Romans and Ritual Murder », Journal of the American Academy of Religion 78, p. 516-541. StAPLes, Ariadne, 1998, From Good Goddess to Vestal Virgins. Sex and category in Roman religion, London - New York. TÁkACs, Sarolta, 2008, Vestal Virgins, Sibyls and Matrons. Women in Roman Religion, Austin.

ThÉBAUd, Françoise, 1998, Écrire I'histoire des femmes, Paris.

VAn Haeperen, Françoise, 2002, Le Collège Pontifical (3ème s.a.C.-4ème s.p.C.), Turnhout.

WildFANG, Robin Lane, 2006, Rome's Vestal Virgins. London - New York.

WinkLer, John, 1990, The Constraints of Desire: The Anthropology of Sex and Gender in Ancient Greece, New York [tr. fr. Sandra Boehringer \& Nadine Picard, Désir et contraintes en Grèce ancienne, Paris, 2005].

ZABEeH, Farhang, 1968, What is in a Name? An Inquiry into the Semantics and Pragmatics of Proper Names, The Hague. 